\title{
Pengaruh Zonasi Dalam Kandang Closed House Terhadap Profil Darah Merah Ayam Broiler
}

\section{The Effect of Zonation in Closed House to Red Blood Cells Profile Broilers}

\author{
I. Brilianto, T. A. Sarjana*, dan R. Murwani \\ Laboratorium Produksi Ternak Unggas, Program Studi Peternakan, Departemen Peternakan, Fakultas \\ Peternakan dan Pertanian, Universitas Diponegoro, Semarang \\ *E-mail: teysar_adi@undip.ac.id
}

(Diterima: 29 Januari 2019; Disetujui: 15 Maret 2019)

\begin{abstract}
ABSTRAK
Penelitian ini dilakukan dengan tujuan untuk mengkaji dampak dari pengaruh zonasi dalam kandang closed house terhadap profil darah merah ayam broiler di musim kemarau. Materi yang digunakan yaitu 720 ayam broiler unsexed dengan bobot awal 49 $\pm 1,13$ gram dipelihara dalam kandang closed house berukuran panjang 60 meter dan lebar 12 meter. Penelitian ini dilaksanakan menggunakan Rancangan Acak Kelompok (RAK) dengan 4 perlakuan dan 6 ulangan, setiap ulangan terdiri dari 30 ekor ayam. Perlakuan berupa zona yang berbeda dari inlet sebagai berikut: 0 (Z1), 1/4 (Z2), 1/2 (Z3) dan 3/4 (Z4) panjang closed house. Hasil penelitian menunjukkan pada zona 4 yang menjauhi inlet jumlah eritrosit, hemoglobin dan Mean Corpuscular Haemoglobin Concentration (MCHC) menurun secara signifikan $(\mathrm{P} \leq 0,05)$ sedangkan pada hematokrit, Mean Corpuscular Volume (MCV) dan Mean Corpuscular Haemoglobin (MCH) tidak terpengaruh secara signifikan $(\mathrm{P}>0,05)$. Zona yang semakin jauh dari inlet menurunkan profil darah merah ayam broiler.
\end{abstract}

Kata kunci: ayam broiler, closed house, kadar amonia, profil darah merah, zonasi

\section{ABSTRACT}

The aim of the research was to evaluate the effect of zonation in a closed house to red blood cells profile of broilers in the dry season. 720 unsexed broilers used with initial weight $49 \pm 1.13 \mathrm{~g}$ are kept in a closed house with length $x$ width $=60 \times 12 \mathrm{~m}$. This study was conducted using Randomized Block Design $(R B D)$ with 4 treatments and 6 replications, each replication consisting of 30 chickens. The treatment consisted of different zone from inlet 0 (Z1), 1/4 (Z2), 1/2 (Z3) and 3/4 (Z4) the length of the closed house from the air inlet. The result showed that in zone 4 significantly $(P \leq 0.05)$ decreased erythrocytes, hemoglobin, and $M C H C$, but hematocrit, $M C V$, and $M C H$ were not significantly affected (P>0.05). It can be concluded that the zone further away from the inlet in a closed house decreased red blood cells profile in broilers.

Keywords: ammonia level, broilers, closed house, red blood cells, zonation

\section{PENDAHULUAN}

Indonesia sebagai daerah tropis memiliki suhu yang tinggi saatmusim kemarau. Data BMKG bulan Juni - Juli tahun 2017 menunjukkan bahwa rata-rata curah hujan 50$100 \mathrm{~mm}$ dan suhu $25-33^{\circ} \mathrm{C}$. Peningkatan suhu makroklimat akan berkontribusi terhadap perubahan suhu dalam kandang, sehingga akan mempengaruhi kadar amonia melalui proses volatilisasi amonia (Sarjana et al., 2018). Faktor yang mempengaruhi tingginya kadar amonia dalam kandang yaitu suhu dan kelembaban udara (Ndegwa et al., 2008; Pokhparel, 2010; dan Sarjana et al., 2017). Kadar Amonia yang tinggi dalam kandang tersebut dapat mengganggu fisologis ayam yaitu menimbulkan iritasi pada lapisan 
mukosa saluran pernafasan (Kristensen dan Wathes, 2000). Selain gangguan fisiologis, amonia juga mengganggu pertumbuhan ayam broiler. Paparan amonia sebesar $50 \mathrm{ppm}$ dapat menurunkan bobot badan ayam broiler sebesar 17\%, sedangkan paparan $75 \mathrm{ppm}$ menurunkan bobot badan $20 \%$ pada umur 7 minggu (Aziz dan Barnes, 2010). Paparan 25 ppm dalam kandang ayam broiler pada umur 35 hari menyebabkan penurunan hemoglobin sebesar 0,09 g/dL dan hematokrit sebesar 0,27\% (Olanrewaju et al., 2008). Penelitian ini dilakukan untuk mengkaji pengaruh zonasi dalam kandang closed house terhadap profil sel darah merah ayam broiler di musim kemarau.

\section{MATERI DAN METODE}

Penelitian dilakukan pada kandang closed house komersial dengan kapasitas 11.000 ekor dengan ukuran $60 \times 12$ meter selama 33 hari. Dari 11.000 ekor tersebut diambil 720 ekor ayam broiler dengan bobot awal 49 $\pm 1,13$ gram dipisahkan untuk dimasukkan ke dalam masing - masing unit (sekat). Setiap unit perlakuan diisi sebanyak 30 ekor ayam. Pakan yang digunakan yaitu pakan komersial S10 dari umur 1 - 14 hari, S11 dari umur 15 - 27 hari dan S12 dari umur 28 - 35 hari yang berasal dari PT. Charoen Pokphand. Bahan litter berasal dari sekam padi dengan sistem penambahan sekam di atasnya. Ilustrasi penempatan zona pada kandang closed house disajikan pada Gambar 1.

Penelitian ini dilaksanakan menggunakan Rancangan Acak Kelompok (RAK) dengan 4 perlakuan dan 6 ulangan, setiap ulangan terdiri dari 30 ekor ayam. Perlakuan adalah pembagian zonasi dalam kandang closed house yang dibagi menjadi 4 zona sebagai berikut: zona 1 (diukur pada jarak $0 \mathrm{~m}$ dari inlet), zona 2 (diukur pada jarak $1 / 4$ panjang kandang atau $15 \mathrm{~m}$ dari inlet), zona 3 (diukur pada jarak $1 / 2$ panjang kandang atau $30 \mathrm{~m}$ dari inlet), zona 4 (diukur pada jarak $3 / 4$ panjang kandang atau $45 \mathrm{~m}$ dari inlet). Pada penelitian ini juga diamati kadar amonia dari masing-masing zona. Hasil rata-rata kadar amonia dari setiap zona disajikan pada Tabel 1.

Sebanyak 2 ekor dari masingmasing unit diambil untuk pengambilan sampel profil darah merah saat ayam umur 28 hari dan selanjutnya serum dianalisis menggunakan alat hematology analyzer. Metode yang digunakan dalam pengujian hemoglobin yaitu Cyanide Free Hemoglobin Spectrophotometry, sedangkan untuk pengujian eritrosit, hematokrit dan leukosit menggunakan metode Elektronic Impedance. Perhitungan indeks darah merah ( $\mathrm{MCV}, \mathrm{MCH}$ dan $\mathrm{MCHC}$ ) diperoleh menggunakan rumus sebagai berikut:

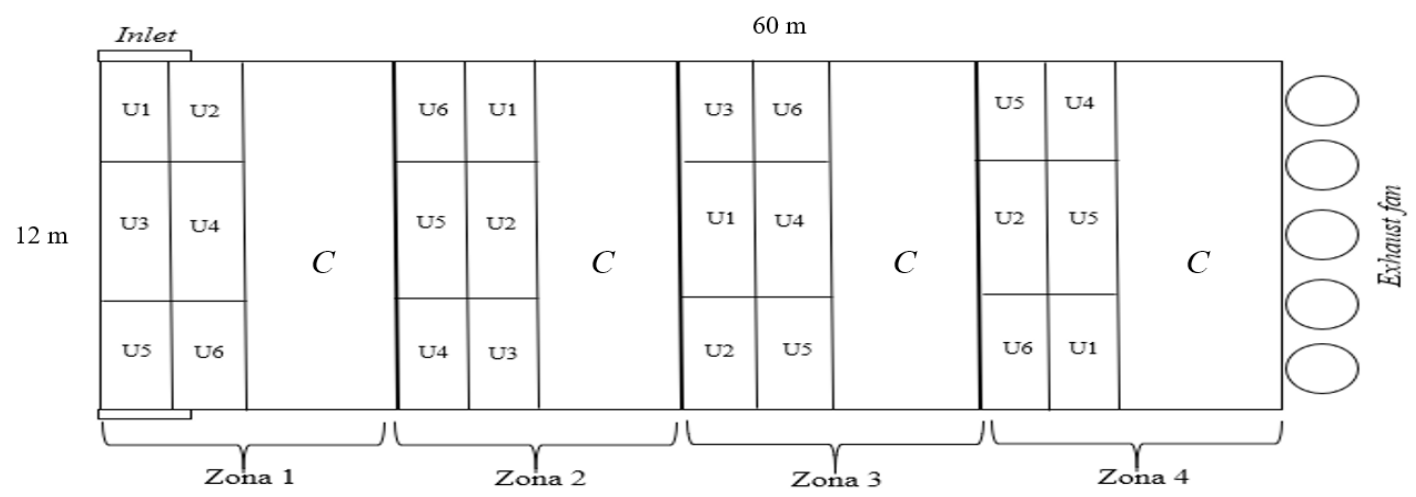

Gambar 1. Pembagian Zona dalam Kandang Closed House. $(C=$ ayam broiler yang dipelihara dalam kandang closed house tetapi tidak ikut dalam perlakuan) 
Tabel 1. Kadar Amonia dalam Kandang Closed House

\begin{tabular}{lcccc}
\hline & Zona 1 & Zona 2 & Zona 3 & Zona 4 \\
\hline Kadar Amonia $(\mathrm{ppm})$ & $1,74 \pm 0,74$ & $2,82 \pm 0,74$ & $4,38 \pm 1,23$ & $6,56 \pm 1,83$ \\
\hline
\end{tabular}

Mean corpuscular volume (MCV)

$$
\operatorname{MCV}(\mathrm{fl})=\frac{\text { Hematokrit } \times 10}{\text { Total Eritrosit }}
$$

Mean corpuscular haemoglobin (MCH)

$$
\mathrm{MCH}(\mathrm{pg})=\frac{\text { Hemoglobin } \times 10}{\text { Total Eritrosit }}
$$

Mean corpuscular haemoglobin concentration (MCHC)

$$
\operatorname{MCHC}(\%)=\frac{\text { Hemoglobin } \times 100}{\text { Hematokrit }}
$$

Data diuji secara statistik dengan analisis ragam untuk mengetahui pengaruh perlakuan dan apabila terdapat pengaruh yang signifikan maka dilakukan uji lanjut Duncan pada taraf signifikasi 5\%.

\section{HASIL DAN PEMBAHASAN}

Hasil penelitian menunjukkan bahwa zonasi signifikan menurunkan $(\mathrm{P} \leq 0,05)$ jumlah eritrosit, hemoglobin dan $\mathrm{MCHC}$ sedangkan hematokrit, MCV dan MCH tidak signifikan dipengaruhi zonasi $(\mathrm{P}>0,05)$ (Tabel 2).

Zonasi dalam kandang closed house signifikan menurunkan jumlah eritrosit ayam broiler. Hal ini karena diduga berhubungan dengan kadar amonia dalam zona 3 dan zona 4 yang lebih tinggi. Amonia ini menyebabkan iritasi pada saluran pernafasan (Kristensen dan Wathes, 2000), menimbulkan stres oksidatif dan gangguan absorpsi nutrien di mukosa usus broiler (Zhang et al., 2015), mengganggu termoregulasi ayam broiler, serta menurunkan konsumsi pakan dan bobot badan (Yahav, 2004; Ibahim dan Allaily, 2012). Penurunan konsumsi pakan dan gangguan absorpsi nutrien tersebut dapat menyebabkan turunnya konsumsi dan absorpsi protein sebagai bahan pembentukan eritrosit. Apabila konsumsi dan absorpsi protein pada broiler turun, maka proses eritropoesis kemungkinan terganggu sehingga pembentukan eritrosit terhambat. Pada penelitian ini jumlah eritrosit turun pada zona 3 dan 4, dimana pada kedua zona tersebut kadar amonia sebesar 4,37 dan 6,56 ppm. Menurut Rachmawati (2000), amonia mulai tercium baunya pada kadar 5 ppm dan pada kadar 6 ppm menimbulkan iritasi pada mukosa mata dan saluran pernapasan ayam. Pada penelitian ini paparan amonia kurang dari 7 ppm sudah dapat mempengaruhi jumlah eritrosit ayam broiler.

Zonasi dalam kandang closed house juga signifikan menurunkan kadar hemoglobin. Kadar hemoglobin zona 1 adalah 9,45 g/dL, kadar hemoglobin zona 2 adalah 9,00 g/dL, kadar hemoglobin zona 3 adalah 9,77 g/dL dan kadar hemoglobin zona 4 adalah 7,26 g/ dL (Tabel 2). Menurut Dharmawan (2002) menyatakan bahwa kisaran normal nilai hemoglobin ayam adalah 7,00 - 13,00 g/dL. Hemoglobin merupakan komponen eritrosit yang berfungsi sebagai pengikat oksigen jika jumlah eritrosit turun maka kadar hemoglobin juga akan ikut turun. Hasil penelitian Olanrewaju et al. (2008) menunjukkan bahwa hemoglobin ayam broiler yang terpapar amonia $25 \mathrm{ppm}$ pada umur 35 hari sebesar 7,60 g/dL dan penurunan $\mathrm{O}_{2}$ sebesar 1,44\%. Penelitian lainnya pada ikan menunjukkan paparan amonia dari lingkungan (perairan) menyebabkan hemoglobin darah turun dan diikuti penurunan konsumsi oksigen (Tilak et al., 2007). Tingginya kadar amonia pada lingkungan zona 4 diduga menyebabkan turunnya kadar hemoglobin broiler karena amonia merupakan salah satu bentuk stress bagi ayam. 
Vol. 21 (2): 59-63

Tabel 2. Profil Darah Merah pada Ayam Broiler

\begin{tabular}{lcccccc}
\hline \multirow{2}{*}{ Parameter } & \multicolumn{4}{c}{ Perlakuan } & \multirow{2}{*}{ P } & \multirow{2}{*}{ SE } \\
\cline { 2 - 4 } & Zona 1 & Zona 2 & Zona 3 & Zona 4 & & \\
\hline Eritrosit (x10 $/ \mathrm{ul})$ & $2,04^{\mathrm{a}} \pm 0,33$ & $2,40^{\mathrm{a}} \pm 0,31$ & $2,19^{\mathrm{ab}} \pm 0,29$ & $1,63^{\mathrm{b}} \pm 0,45$ & 0,05 & 0,14 \\
Hemoglobin (g/dL) & $9,45^{\mathrm{a}} \pm 1,63$ & $9,00^{\mathrm{ab}} \pm 0,78$ & $9,77^{\mathrm{a}} \pm 1,19$ & $7,26^{\mathrm{b}} \pm 2,12$ & 0,04 & 0,62 \\
Hematokrit (\%) & $26,33 \pm 34,06$ & $27,05 \pm 4,50$ & $29,07 \pm 3,52$ & $21,83 \pm 6,75$ & 0,10 & 1,99 \\
MCV (fl) & $129,33 \pm 3,72$ & $132,12 \pm 1,80$ & $133,35 \pm 5,20$ & $135,33 \pm 6,30$ & 0,18 & 1,87 \\
MCH (pg) & $46,22 \pm 2,06$ & $44,73 \pm 6,29$ & $44,65 \pm 1,71$ & $43,78 \pm 1,88$ & 0,70 & 1,45 \\
MCHC (g/dL) & $35,77^{\mathrm{ab}} \pm 1,53$ & $36,75^{\mathrm{a}} \pm 2,10$ & $33,63^{\mathrm{bc}} \pm 2,23$ & $32,63^{\mathrm{c}} \pm 1,86$ & 0,01 & 0,80 \\
\hline
\end{tabular}

Keterangan: Superskrip yang berbeda dalam baris yang sama menunjukkan perbedaan yang signifikan $(\mathrm{P} \leq 0,05)$.

Zonasi dalam kandang closed house tidak signifikan terhadap kadar hematokrit. Rata - rata kadar hematokrit selama penelitian adalah 21,83 - 29,07\%. Hasil penelitian Satyanigntyas et al. (2010) menunjukkan bahwa nilai hematokrit normal ayam broiler adalah 22,50\%. Hematokrit adalah perbandingan sel darah merah dengan volume darah keseluruhan (eritrosit, leukosit dan trombosit). Pada penelitian ini hasil hematokrit didapatkan hasil tidak signifikan, karena hematokrit merupakan rasio yang tidak hanya tersusun dari eritrosit sehingga hematokrit tidak dipengaruhi kadar amonia dalam kandang yang relatif masih rendah.

Penentuan nilai MCV, $\mathrm{MCH}$ dan MCHC untuk mengidentifikasi kondisi fisologis ternak tersebut. Nilai MCV normal pada ayam 90,00 - 140,00 fl, nilai $\mathrm{MCH}$ normal sebesar 33,00 - 47,00 pg dan nilai MCHC berkisar 26,00 - 35,00\% (Swenson dan William, 1993; Jain, 1993; Ulupi dan Ihwantoro, 2014). Nilai indeks eritrosit yang tidak normal diindikasikan ternak tersebut mengalami anemia yang dapat dipicu dari eritropoetin (Fahmi et al., 2017). Nilai MCHC pada penelitian ini signifikan menurun $(\mathrm{P} \leq 0,05)$. MCHC merupakan rasio hemoglobin terhadap hematokrit. Penurunan nilai $\mathrm{MCHC}$ tersebut dipengaruhi oleh nilai hematokrit dan hemoglobin dalam darah. Nilai hemoglobin yang turun dibagi nilai hematokrit yang tetap pada penelitian ini maka didapatkan nilai MCHC yang juga turun. Turunnya nilai hemoglobin akibat dari pengaruh kadar amonia dalam kandang, karena amonia menyebabkan stress bagi ayam broiler. $\mathrm{MCH}$ adalah nilai hemoglobin dibagi dengan jumlah eritrosit, dari data penelitian ini nilai hemoglobin dan jumlah eritrosit dari zona 1 ke zona 4 sama-sama menurun sehingga didapatkan nilai $\mathrm{MCH}$ yang tetap

\section{KESIMPULAN}

Kesimpulan penelitian ini yaitu zona dalam kandang closed house yang semakin jauh dari inlet menurunkan profil darah merah ayam broiler pada musim kemarau.

\section{DAFTAR PUSTAKA}

Aziz, T. dan J. Barnes. 2010. Harmful effects of ammonia on birds.Rollin Animal Disease Diagnostic Laboatory Departement of Agriculture and Consumer ServicesCollege of Veterine Medicine. NC State University. Raleigh, NC, USA.

Dharmawan, N. S. 2002. Pengantar Patologi Klinik Veteriner (Hematologi Klinik). Cetakan III. Pelawa Sari, Denpasar.

Fahmi, F. W., E. Widiastuti dan Sugiharto. 2017. Pengaruh perbedaan lama waktu pemberian Spirulina platensis 
dalam ransum terhadap profil darah merah ayam broiler. Jurnal Ilmu-Ilmu Peternakan. 27 (3): $54-62$.

Ibrahim, S. dan Allaily. 2012. Pengaruh berbagai bahan litter terhadap konsentrasi amonia udara ambient kandang dan performan ayam broiler. Agripet. 1 (12): 47 - 51.

Jain, N. C. 1993. Essential of Veterinary Hematology. Lea \& Febiger, Philadelphia.

Zhang, J., C. Li., X. Tang., Q. Lu., R. Sa and H. Zhang. 2015. Proteome changes in the small intestinal mucosa of broilers (Gallus gallus) induced by high concentrations of atmospheric ammonia. Proteome Science 13:9.

Kristensen, H. H. dan C. M. Wathes. 2000. Ammonia and poultry welfare: a review. World's Poultry Science Journal. 56 (3): $235-245$.

Ndegwa, P.M., A.N. Hristov., J. Arogo, dan R.E. Sheffield. 2008 A review of ammonia emissionmitigation techniques for concentrated animal feeding operation. Biosystems Engineering. $100: 453-469$.

Olanrewaju, H. A., J. P. Thaxton, W. A. Dozier III, J. Purswell., S. D. Collier, dan S. L. Branton. 2008. Interactive effects of ammonia and light intensity on hematochemical variables in broiler chickens. Poultry Science. 87: 1407 1414.

Pokharel, B. B. 2010. Ammonia Emission From Poultry Industry, Its Effects And Mitigation Mechanism.

Rachmawati, S. 2000. Upaya pengelolaan lingkungan usaha peternakan ayam. Wartazoa. 9 (2): $73-80$.

Sarjana, T. A., L. D. Mahfudz, D. Sunarti, W. Sarengat, N. K. F. Huda, N. A. Rahma, Renata, D. A. Suryani, W.
F. Arfianta dan B. Mustaqim. 2018. Perbedaan kondisi makroklimat akibat zona penempatan di closed house ayam broiler. Prosiding Seminar Nasional Kebangkitan Nasional III. 3 Mei 2018. Semarang, Indonesia.

Sarjana, T. A., L. D. Mahfudz, M. Ramadhan, Sugiharto, F. Wahyono, dan S. Sumarsih. 2017. Kadar amonia dan kondisi litter pada kendang ayam broiler sistem terbuka yang mendapatkan additif berbeda dan kombinasinya dalam ransum. Prosiding Seminar Nasional PengembanganPeternakan Berkelanjutan 9. 15 November 2017. Sumedang, Indonesia.

Satyaningtijas, A. S., S. D. Widhyari dan R. D. Natalia. 2010. Jumlah Eritrosit, Nilai Hematokrit dan Kadar Hemoglobin Ayam Pedaging Umur 6 Minggu yang Diberi Suplemen Kunyit, Bawang Putih dan Zink. Jurnal Kedokteran Hewan. 4 (2): $69-73$.

Swenson, M. J. dan O. R. William. 1993. Duke's Physiology of Domestic Animals. Ed ke-11. Publishing Assocattes a Division of Cornell University, Ithaca and London.

Tilak, K. S., K. Veeraiah dan J. M. P. Raju. 2007. Effects of ammonia, nitrite and nitrate on hemoglobin content and oxygen consumption of freshwater fish, Cyprinus carpio (Linnaeus). Journal of Environmental Biology. 28 (1): 45 - 47.

Ulupi, N, dan Ihwantoro. T. 2014. Gambaran darah ayam kampungdan ayam petelur komersial pada kandang terbuka di daerah tropis. Jurnal Ilmu Produksi dan Teknologi Hasil Peternakan. 2(1): 219223.

Yahav, S. 2004. Ammonia affects performance and thermoregulation of male broiler chickens 1. Anim. Res 53, 289-293. 